\title{
Plantlet Formation from the Callus of Primary Leaf in Sword Bean [Canavalia gladiata (JACQ) DC]
}

\author{
Koichi OzAKI \\ Crop Division, Okayama Agricultural Experimental Station, \\ Sanyo-cho, Okayama, 709-08 Japan
}

(Received September 18, 1992)

(Accpted October 20, 1992)

\begin{abstract}
The immature leaflets from 5 day old seedlings of sword bean regenerated adventitious buds on MS medium containing B5 vitamin, $500 \mathrm{mg} / l$ casamino acid, $0.01 \mathrm{mg} / l \mathrm{NAA}$ and $1.0 \mathrm{mg} / l \mathrm{BA}$, but the immature leaflets from 10 day old seedlings did not regenerate adventitious buds. After adventitious buds were transferred to the $1 / 2 \mathrm{MS}$ medium containing $1.0 \mathrm{mg} / l \mathrm{NAA}$ and $0.01 \mathrm{mg} / l \mathrm{BA}$, root developed.
\end{abstract}

\section{Introduction}

In cell fusion, leaves are frequently used as the material for the isolation of protoplast. So, plant regeneration from callus derived from leaves is very important in crop improvement using tissue culture. However, there are not many reports of the regeneration of legumes from immature leaflets. It was achieved successfully only in Vigna radiata ${ }^{1)}$. Arachis hypogaea ${ }^{2)}$, Pisum sativum ${ }^{3}$, Vigna angularis ${ }^{4}$, Lupinus luteus ${ }^{5)}$, L. hartwagii ${ }^{5)}$, L. angustifolius ${ }^{5)}$ and Glycine max ${ }^{6}$. Six years ago, the author reported $^{7)}$ on the regeneration of plantlets from the hypocotyle and shoot meristem of sword bean. It was the first report on the tissue culture of sword bean. Since then no one has made further reports about sword bean. So, as a continuation of the former research, this report describes the procedure employed in the regeneration of sword bean from immature leaflets.

\section{Materials and Methods}

Seeds of the sword bean [Canavalia gladiata (JACQ) DC] cultivar Shirobana were used in this experiment. The seed surface was sterilized in $70 \%$ ethanol for $10 \mathrm{sec}$. followed by immersion in $1.0 \%$ sodium hypochlorite solution for $20 \mathrm{~min}$. The seeds were rinsed three times with sterile double-distilled water. They were germinated on MS medium lacking hormones in $100 \mathrm{~m} l$ flasks (one seed per flask).

After 5 days of inoculation, a pair of yellowish-white immature leaflets was aseptically dissected from inside of the cotyledon under a stereo microscope. Approximately two-thirds of the distal portion was placed in $20 \times 100 \mathrm{~mm}$ test tubes (one explant per tube) in $10 \mathrm{~m} l$ of nutrient medium solidified with $0.8 \%$ agar.

In one experiment, the leaflets of 10 day old seedlings were employed as the explants.

The nutrient medium consisted of MS salts, $3 \%$ sucrose and vitamins as in the B5 medium, and $500 \mathrm{mg} / l$ casamino acid. Naphthalene acetic acid (NAA) and 6-benzyladenine (BA) were added in various combinations and concentrations as shown in Table 1. The $\mathrm{pH}$ of the medium was adjusted 
Table 1. Effect of NAA and BA combinations on the morphogenetic response from immature leaflets of sword bean.

\begin{tabular}{|c|c|c|c|c|c|c|c|c|c|c|}
\hline \multirow{3}{*}{\multicolumn{2}{|c|}{$\underset{(\mathrm{mg} / l)}{\mathrm{NAA}}$}} & \multirow{3}{*}{$\begin{array}{c}\text { No of } \\
\text { explant }\end{array}$} & \multicolumn{7}{|c|}{ age of seedling } & \\
\hline & & & \multicolumn{4}{|c|}{5 days old $(\%)$} & \multicolumn{4}{|c|}{10 days old (\%) } \\
\hline & & & $\begin{array}{l}\text { callus } \\
\text { formation }\end{array}$ & $\begin{array}{l}\text { callus } \\
+ \text { shoot }\end{array}$ & $\begin{array}{l}\text { callus } \\
+ \text { root }\end{array}$ & NR & $\begin{array}{l}\text { callus } \\
\text { formation }\end{array}$ & $\begin{array}{l}\text { callus } \\
\text { + shoot }\end{array}$ & $\begin{array}{l}\text { callus } \\
+ \text { root }\end{array}$ & NR \\
\hline \multirow[t]{4}{*}{0} & 0.01 & 20 & 0 & 0 & 0 & 100 & 0 & 0 & 0 & 100 \\
\hline & 0.1 & 20 & 80 & 0 & 0 & 20 & 40 & 0 & 0 & 60 \\
\hline & 1. 0 & 20 & 100 & 0 & 0 & 0 & 70 & 0 & 0 & 30 \\
\hline & 4. 0 & 20 & 45 & 0 & 0 & 55 & 100 & 0 & 0 & 0 \\
\hline \multirow[t]{4}{*}{0.01} & 0.01 & 20 & 100 & 0 & 0 & 0 & 100 & 0 & 0 & 0 \\
\hline & 0.1 & 20 & 100 & 0 & 0 & 0 & 100 & 0 & 0 & 0 \\
\hline & 1. 0 & 20 & 75 & 25 & 0 & 0 & 100 & 0 & 0 & 0 \\
\hline & 4. 0 & 20 & 100 & 0 & 0 & 0 & 100 & 0 & 0 & 0 \\
\hline \multirow[t]{4}{*}{0.1} & 0.01 & 20 & 100 & 0 & 0 & 0 & 100 & 0 & 0 & 0 \\
\hline & 0.1 & 20 & 100 & 0 & 0 & 0 & 100 & 0 & 0 & 0 \\
\hline & 1. 0 & 20 & 100 & 0 & 0 & 0 & 100 & 0 & 0 & 0 \\
\hline & 4.0 & 20 & 100 & 0 & 0 & 0 & 100 & 0 & 0 & 0 \\
\hline \multirow[t]{4}{*}{1.0} & 0.01 & 20 & 100 & 0 & 0 & 0 & 65 & 0 & 35 & 0 \\
\hline & 0.1 & 20 & 100 & 0 & 0 & 0 & 100 & 0 & 0 & 0 \\
\hline & 1.0 & 20 & 100 & 0 & 0 & 0 & 100 & 0 & 0 & 0 \\
\hline & 4. 0 & 20 & 100 & 0 & 0 & 0 & 100 & 0 & 0 & 0 \\
\hline \multirow[t]{4}{*}{4.0} & 0.01 & 20 & 25 & 0 & 75 & 0 & 0 & 0 & 100 & 0 \\
\hline & 0.0 & 20 & 70 & 0 & 30 & 0 & 50 & 0 & 50 & 0 \\
\hline & 1.0 & 20 & 100 & 0 & 0 & 0 & 80 & 0 & 20 & 0 \\
\hline & 4.0 & 20 & 100 & 0 & 0 & 0 & 100 & 0 & 0 & 0 \\
\hline
\end{tabular}

NR : no response

to 5.8 and $0.8 \%$ Difco agar was added before autoclaving.

Each treatment consisted of twenty replications. The enviromental conditions for seed germination and leaflet culture were as follows: constant temperature of $25^{\circ} \mathrm{C}, 12 \mathrm{~h}$ /day photoperiod with fluorescent lamps giving 5000 lux illumination.

\section{Results}

\section{Immmature leaflets of 5 day old seedlings (Table 1)}

After 7 days of culture, most of the explants began to change gradually from yellowish-white to green. The extent of the greening was proportional to the concentration of NAA and BA, and the higher the concentration was, the more pronounced the greening was.

Thereafter callus began to form gradually on the ridge of the explant. After 2 weeks of culture, the explants changed entirely to the callus in every treatment except for $0.01 \mathrm{mg} / l \mathrm{BA}$. The majority of callus formed were soft and yellowish-brown, but in a part of the callus, powdery white tissues were formed on the soft yellowish-brown callus.

After 17 days of culture, adventitious buds were formed from yellowish-brown callus in the 0.01 $\mathrm{mg} / l \mathrm{NAA}$ and $1.0 \mathrm{mg} / l \mathrm{BA}$ treatment. The rate of formation of adventitious buds to the number of explants was 25\%; 5 adventitious buds were formed on the 20 explants ( 1 adventitious bud was formed on each of 5 explants). The shoot elongated to $10 \mathrm{~cm}$ after one month (Fig. 1).

Afterward, 5 shoots were transferred to $1 / 2 \mathrm{MS}$ medium containing $1.0 \mathrm{mg} / l \mathrm{NAA}$ and $0.01 \mathrm{mg} /$ $l \mathrm{BA}$, so that all could develop roots and became perfect plantlets (Fig. 2).

Afterward, when only 20 explants were cultured on the $0.01 \mathrm{mg} / l \mathrm{NAA}$ and $1.0 \mathrm{mg} / l \mathrm{BA}$ treat- 


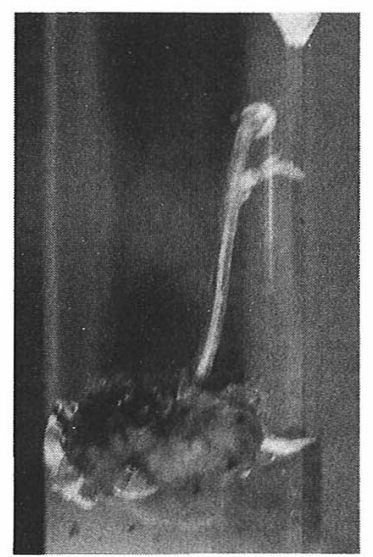

Fig. 1 Shoot formation from the callus derived from primary leaf of sword bean.

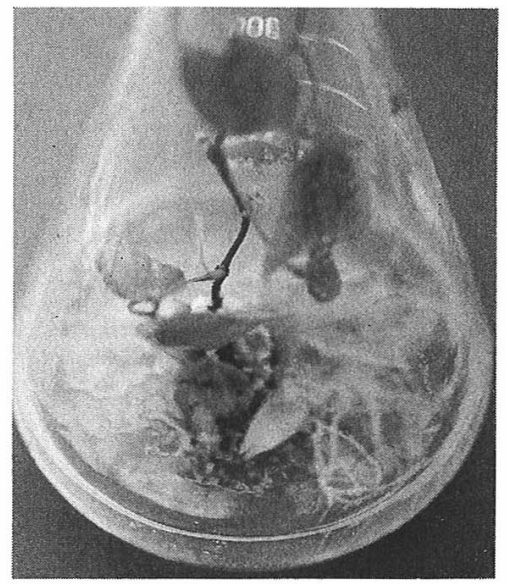

Fig. 2 Plantlet from the primary leaf explant of sword bean.

ment again, the rate of formation of adventitious buds was $20 \%$ of the number of explants. All adventitious buds became perfect plantlets.

\section{Immature leaflets of 10 day old seedlings (Table 1)}

The response of the explant, during the culture, was delayed compared with the 5 day old seedlings. Also the rate of callus formation was lower than in the 5 day old seedlings. In addition, advetitious buds were not formed from yellowish-brown callus in any of treatments, even after one month of culture.

\section{Discussion}

Based on the results mentioned above, it was shown that plantlets were able to regenerate from primary leaves of sword bean.

In the case of azuki bean, mungbean, lupin and bean, when the callus derived from primary leaves was transfered to the regeneration medium containing cytokinin, adventitious buds were formed on the callus. However, in the case of sword bean, like pea and peanut, adventitious buds were formed on the callus derived from primary leaves without transfering the callus to the regeneration medium.

Compared with pea ${ }^{2)}$ and peanut ${ }^{3)}$, where adventitious bud formation from primary leaves occured in many combinations of NAA and BA, sword bean adventitious bud formation was restricted to 
only one combination of NAA and BA. Also, while the rate of formation of advetitious buds to the number of explants ranged from $70 \%$ to $90 \%$ in the case of peanut and $35 \%$ in the case of pea, the corresponding value was $25 \%$ in the case of sword bean.

Based on the results obtained, it is assumed that plantlet regeneration from the primary leaves of sword bean is a little more difficult than in pea and peanut, but is easier than azuki bean, mungbean and lupin.

The age of the leaf is very important, because the regeneration rate from primary leaf decreased sharply with the age of leaf as in the case of other legumes.

As plantlet regeneration of legumes from primary leaf had been successfully achieved only in mungbean, pea, peanut, azuki bean, lupin and bean, the findings currently reported are noteworthy.

\section{References}

1) Mendosa, A. B., K. Hattori, Y. Futsuhara, 1992. Japan. J. Breed., 42 : 145-149.

2) Mroginski, L. A., K. K. Kartha, J. P. Shyluk, 1981. Can. J. Bot., 59 : 826-830.

3) Mroginski, L. A., K. K. Kartha, 1981. Plant Cell Rep., 1 : 64-66.

4) Ozaki, K., 1986. Japan. J. Breed., $36: 139-143$.

5) Sator, C., 1985. Pl. Cell. Rep., $4: 126-128$.

6) Wright, M. S., D. V. Ward, M. A. Hincee, M. G. Carnes, R. J. Kaufman, 1987. Plant Cell Rep., 6 : 83-89.

7) Ozaki, K., 1986. Plant Tissue culture letters, 3(2): 78-82.

\section{《和文要約》}

ナタマメの初生葉由来カルスからの植物体再生

尾崎厚一

岡山農業試験場

\footnotetext{
ナタマメ末展開葉からの植物体の再生を検討するため, Murashige and Skoog(MS) 培地の無機塩に B5 培地のビタミンとカザミノ酸 $500 \mathrm{mg} / l$ を加え, NAA と BA の濃度を組み合わせて検討した. 播種後 5 日 目に採取した材料からはNAA $0.01 \mathrm{mg} / l, \mathrm{BA} 1.0 \mathrm{mg} / l$ の場合にカルス経由で不定芽が形成された. しか し播種後 10 日目に採取した材料からは不定芽の形成は認められなかった．また形成された不定芽を $1 / 2$ MS 培地に NAA $1.0 \mathrm{mg} / l$ と BA $0.01 \mathrm{mg} / l$ を添加した発根培地へ移したところ植物体が形成された。
} 